\title{
Politics, power, and precarity: how tenant organizations transform local political life
}

\author{
Jamila Michener ${ }^{1}$ D $\cdot$ Mallory SoRelle ${ }^{2}$
}

Accepted: 13 December 2021 / Published online: 14 February 2022

(C) The Author(s), under exclusive licence to Springer Nature Limited 2022

\begin{abstract}
As the coronavirus pandemic exacerbated housing precarity, tenant organizations grew in numbers and salience. But membership-based tenant organizations predated the pandemic and will persist beyond it. There are (at least) hundreds of them in localities across the country. Many aim to advance sweeping change. In doing so, they face formidable tasks: politically organizing in race-class subjugated communities, working in opposition to powerful actors (corporate landlords, property managers, etc.), and navigating complex and sometimes hostile local political institutions (city councils, mayors, rent boards, etc.). How do these organizations build power and effect change in the face of such obstacles? Drawing on a rich body of original qualitative evidence (participant observation and in-depth interviews), this paper explores the politics of local tenant organizations. We assess the origins of such organizations, how they are structured, and how they pursue political change. In doing so, we offer a rich descriptive account of phenomena that have largely escaped the attention of political scientists. We find that tenant organizations can cultivate radically different ways of conceptualizing political economy, carve out a distinctive political focus on race-class subjugated communities, and create critical opportunities for otherwise marginalized actors to develop and exercise political power.
\end{abstract}

Keywords Tenant organizations $\cdot$ Housing $\cdot$ Power $\cdot$ Organizing $\cdot$ Politics

Jamila Michener

jm2362@cornell.edu

1 Department of Government and Brooks School of Public Policy, Cornell University, 123 Central Ave, Ithaca, NY 14850, USA

2 Sanford School of Public Policy, Duke University, 210 Sanford Building, Durham, NC 27708, USA 


\section{Introduction}

Laura, ${ }^{1}$ a middle-aged Black woman living in Western New York, was saved from houselessness when her neighbors physically surrounded her home-stopping the local police from executing an eviction. Laura's neighbors deployed a tactic known as an eviction blockade. When sheriffs showed up to evict Laura, a throng of neighbors and supporters encircled her home. Police saw the scale of the gathering and decided to delay the eviction. This happened numerous times over several years. Each time Laura was scheduled for an eviction, her neighbors rallied and the eviction was postponed. Eventually, Laura's bank ceased eviction proceedings altogether, opting instead to negotiate more favorable terms that allowed her to remain in her home.

The eviction blockades that kept Laura housed were coordinated by a grassroots membership-based tenant led organization called Housing NOW. ${ }^{2}$ Housing NOW found Laura's name on a housing court roster, contacted her, and asked her if she wanted help combatting her eviction. Laura accepted their offer. Being part of Housing NOW transformed Laura's political life. After securing her own housing, she continued working with Housing NOW to organize her neighbors against predatory landlords and banks. Even more striking is how these efforts changed local political dynamics in Laura's community. The threat of eviction blockades and other forms of direct action altered landlord-tenant dynamics, strengthening the position of tenants. Landlords who were fearful of being targeted by Housing NOW halted eviction proceedings and instead negotiated terms with tenants that kept them in their homes. Local elected officials made housing a more central aspect of their campaign platforms, showed up at direct action events organized by Housing NOW, and talked with the group about changing local policies. As media coverage of eviction blockades spotlighted the role of law enforcement, there was increasing pressure to reevaluate the involvement of police in eviction processes. The efforts of groups like Housing NOW point to a larger reality: collective organizing among people fighting precarious and insecure housing is occurring in localities across the country. Not only does this organizing produce political opportunities for individuals, it also structures the realities of local politics.

Ample research on American politics suggests that people like Laura and her neighbors have woefully constrained political power (Franko 2013; Gilens 2012; Hajnal and Trounstine 2016; Nuamah 2020; Piven et al. 2009; Schlozman et al. 2012; Soss and Weaver 2017: 583). Indeed, race-class subjugated (RCS) ${ }^{3}$ populations are positioned in the crosshairs of social and political exclusion: living in or near poverty, working low-wage jobs, residing in "bad" neighborhoods, and having politically debilitating encounters with carceral and welfare state institutions. Each of these experiences-from economic deprivation to bereft neighborhood conditions

\footnotetext{
1 This qualitative narrative is based on participant observation. All names of research participants are anonymized in order to protect confidentiality.

2 Organization names and other (non-essential) details are altered to ensure anonymity.

3 We follow Soss and Weaver (2017, p. 567) in using the phrase "race-class subjugated." Such language recognizes that "race and class are intersecting social structures...that defy efforts to classify people neatly...".
} 
to negative interactions with the state-is typically expected to demobilize people (e.g., Verba et al. 1995; Michener 2013, 2018; Weaver and Lerman 2010). Nevertheless, narratives like Laura's highlight the prospects for marginal denizens to engage in critical forms of politics and to build political power in their communities. This is consistent with what we have learned from scholars who have marked the contours of resistance and political agency among subaltern groups (Cohen 2004; Kelley 1990, 1996; Piven and Cloward 1977; Scott 1985). Local, membership-based organizations are a vital locus of such power building (Burghardt 1972; Rodriguez 2021; Han et al. 2021; Michener 2020). In this paper, we attend to a particularly important and growing subset of those groups: tenant organizations.

As the pandemic exacerbated housing instability, renters faced eviction in staggering numbers - about one in five (more than 10 million people) fell behind on their rent payments, even after multiple rounds of Covid stimulus checks. In this context, tenant organizations have grown more salient. There are hundreds of these organizations in localities across the country. Many aim to advance sweeping change. In doing so, they face formidable tasks: politically organizing in race-class subjugated communities, working in opposition to powerful actors (landlords, property managers, etc.), and navigating complex and sometimes hostile local political institutions (city councils, rent boards, etc.). How do tenant organizations build power and affect change in the face of such obstacles? While there is a well-established interdisciplinary literature that attends to the democracy-enhancing functions of various kinds of organizations, tenant organizations have not been incorporated into such studies (Goss 2013; Han 2009, 2014; McAlevey 2016; Skocpol 2003; Skocpol et al. 2000).

Drawing on a rich body of qualitative evidence, including participant observation and in-depth interviews, this paper explores the politics of local tenant organizations. We describe how such organizations develop, how they are structured, and their tactics in pursuing political change. Along the way, we offer a rich account of an organizational type that political scientists have overlooked, thereby missing a crucial form of political engagement within RCS communities. We find that tenant organizations can cultivate radically different ways of conceptualizing the political economy, carve out a distinctive space in local politics by centering economically and racially marginalized communities, and create critical opportunities for marginalized denizens to develop and exercise political power. Tenant groups generate a range of alternatives for imagining and enacting local politics in the context of a capitalist economy marked by striking and enduring racial inequalities.

\section{Housing, power, and local politics}

Housing is a policy arena marked by an enduring history of political struggle. While many "consumer" issues fall short of consistently and sufficiently motivating robust political action (e.g., food prices, consumer protections), housing stands out as an issue that often catalyzes political engagement and energizes political life, even in race-class subjugated communities (Dreier 1984; Thurston 2018; Michener 2020; Rodriguez 2021; SoRelle 2020). 
Housing holds a unique status as an important political issue. It is the largest single expense for most families (PEW 2016). Housing cost burdens for renters have been on the rise as rental markets have seen a proliferation of high-cost units alongside a decline in low-cost units (Joint Center for Housing Studies 2020). Rental prices are at record highs, while vacancy rates (especially in moderate-tolow quality rentals) have reached a relative nadir (Joint Center for Housing Studies 2020). Among other things, this means that tenants cannot "vote with their feet" by simply exiting predatory, substandard, or otherwise adverse housing situations (Tiebout 1956). Such conditions produce painfully limited options for all but the wealthiest classes, while empowering landlords, banks, and elite economic interests. Under these circumstances, durable antagonisms flare between those who are profiting from the housing status quo and those who are hard pressed under its weight. This lays the groundwork for political contestation.

Beyond such structural economic conditions, the relational configuration of housing produces distinct political conditions. Namely, "housing preeminently creates and reinforces connections between people, communities, and institutions, and thus it ultimately creates relationships of power" (Marcuse and Madden 2016: 89). Tenants ${ }^{4}$ are an identifiable group of people who often come into regular contact with one another. This creates opportunities to develop social bonds, commiserate, communicate their struggles, and engage one another in a wide variety of ways. Landlords, banks, property management companies, and those with capital interests in the housing market lie on the other end of the relational spectrum. These actors exercise salient and traceable control over the lives of tenants. The conspicuous clarity of such power arrangements inscribes the residential as political and positions housing as a site for "organizing citizenship, work, identities, solidarities and politics" (Madden and Marcuse 2016: 12).

Importantly, the venue of political contestation over housing is primarily local. Housing is experienced on a local level and understood as a local issue. In the larger scheme of U.S. federalism, housing policy is historically the prerogative of local actors (Kincaid 1992). States sometimes use their power to place constraints on localities (e.g., preemption of local rent control laws) and the federal government offers "people-based" housing resources to support low-income denizens (e.g., the Housing Choice Voucher Program), but many of the most consequential decisions about housing remain squarely in the domain of local politics (Dantzler 2016; Hatch 2017; Trounstine 2018).

A significant body of research on housing-related interest groups has focused on economic elites and non-profit advocacy organizations (Al-Turk 2016; Einstein et al. 2020; Erickson 2006; Lilley 1980; Mollenkopf and Pynoos 1980; Yerena 2015,

\footnotetext{
4 Tenants are defined differently by different groups, depending upon their purpose. Since our purpose in this article is to enhance and expand understanding, we define tenants capaciously, reflecting the range of definitions we encountered while doing research. Per this approach, a tenant is anyone without the ability to comfortably control their access to and/or quality of housing. This includes renters who pay landlords for their housing, but also includes those who are unhoused, as well as home "owners" whose ability to stay housed is precarious and contingent on (sometimes predatory) terms set by banks and other financial institutions or access to land for mobile/manufactured housing.
} 
2019). Another subset of research has attended specifically to organized residents within public housing (Feldman and Stall 2004; Feldman et al. 1998; Howard 2014; Keene 2016; Rodriguez 2021; Williams 2004). However, comprehensive research on tenant organizations writ-large reached its height in the 1970s and $80 \mathrm{~s}$ and has since languished (Atlas and Drier 1980; Burghardt 1972; Capek and Gilderbloom 1992; Dreier 1982, 1984; Lawson 1986; Heskin 1981; Marcuse 1980; MaslowArmand 1986; Shlay and Faulkner 1984). There are 44 million renter households the United States (2019 American Community Survey) and over 2.1 million families that are at least 3 months behind on mortgage payments (Consumer Financial Protection Bureau 2021). Yet, political scientists have largely neglected tenants as political actors. Correspondingly, they have overlooked the role of tenant organizations in building and channeling the power of tenants. Even before a global health pandemic threw the perennial crises of housing into sharp relief, ${ }^{5}$ popular accounts suggested that tenants across the country were "rising" and that their activism was “expanding” (Burns 2018; Kasakove 2019; Lang 2019; Tobias 2019). In the wake of Covid-19, tenant engagement was further catalyzed. Calls to "cancel rent" and organized rent strikes multiplied (Bougslaw 2020; Busch 2021; Haag and Dougherty 2020; Lowrey 2020; Salter 2020). The absence of research on the politics of tenant organizations makes it difficult to discern the significance of these formations. This paper offers a contemporary descriptive account of tenant organizations in the United States, with an eye towards advancing knowledge of what these organizations do, the varied ways they do it, and the implications for local politics and democracy in the places they operate.

\section{Tenant organizations: a hybrid political formation}

What type of organization are tenant groups? As a rule of thumb, organizational typology is a difficult and contested enterprise. Even (or perhaps especially) among scholars of interest groups, there is no widely accepted consensus and no clearly delineated process for defining and distinguishing between an "interest group," an "advocacy group," and a "social movement organization" (Andrews and Edwards 2004; Baroni et al. 2014; Burnstein 2019). There are certainly definitions and distinctions circulating in the literatures(s); however, there is a notable "lack of shared vocabulary" around key terms. Researchers sometimes use the same words while still "talking past each other" (Baumgartner and Leech 1998: 22; Burnstein 2019: 3; Burnstein and Linton 2002). We will not attempt to resolve this definitional ambiguity. However, to ensure that the descriptive picture we offer is not distorted by concerns over how to properly classify tenant organizations, we note

\footnotetext{
5 One potential explanation for the scholarly blind spot vis-à-vis organizing around housing insecurity in RCS communities may stem from what Strolovitch (2013) argues is the political construction of economic crises. That is to say, "conditions of vulnerability, often simply taken for granted as part of the normal social landscape when they affect marginalized populations, become regarded as crises when they affect dominant groups" (167).
} 
that - notwithstanding a wide range of definitional options available in academic literatures-tenant organizations do not neatly fit into the existing landscape of research on interest groups or advocacy groups. This is not surprising. Categorization is an exercise that often exposes a lack of fit between the categories of analysis that scholars develop to gain analytical traction on research topics and the categories of practice that are legible to social and political actors in the real world (Brubaker 2013). If we take organizations' self-understanding into consideration (i.e., their own constructed categories of practice), then tenant organizations emerge as a hybrid form primarily oriented around building power in local communities. Many members of these organizations we interviewed openly eschewed labels such as "advocacy group," "activist group," and most stridently "non-profit organization." Moreover, not once did anyone we interviewed use the words "interest group," and only occasionally did organizational participants categorize their groups as "grassroots."

While we do not argue that tenant groups represent an entirely novel organizational form, we do stress that their lack of obvious fit with the primary categories that predominate literatures on organizations is instructive. A constellation of characteristics and orientations makes tenant organization different: they emphasize power building over advocacy, autonomy over financial security, and deep organizing over superficial activism. Such choices are reflected in organizational discourse and action. All of this has implications for how tenant organizations operate within local politics. In the sections below, we provide concrete qualitative evidence of these and other aspects of tenant organizations. We furnish an in-depth examination that highlights how tenant organizations carve out a distinctive space in local politics by building power around the concerns of economically and racially marginalized communities. A close look at tenant organizations usefully expands our understanding of local political life, particularly in marginalized communities.

\section{Research process and method}

The qualitative findings presented here are derived from participant-observation and in-depth interviews. Participant observation is a type of ethnographic approach that involves embedding oneself in a group or community for an extended period to observe, learn, and chart important phenomena (Burawoy et al. 1991; Gillespie and Michelson 2011). It embraces a bottom-up methodological approach that centers the voices of its subjects (Michener et al. 2020). For this study, we observed and participated in the meetings, workshops, and trainings of tenant organizations across the country over an 8-month period between September 2020 and May 2021. Because we were in a pandemic, all our observation was virtual. After several months of observing-once we had garnered significant knowledge in terms of 
language, structure, and process-we began in-depth interviews with members of tenant organizations across the country.

We interviewed 46 people from 38 organizations. Those organizations were spread across 21 states and 33 localities. The states where organizations in this study operated spanned a wide geographic gamut including the Northeast, Southeast, Northwest, Southwest, Midwest, and Mid-Atlantic. ${ }^{6}$ Similarly, the localities the organizations were embedded within were heterogenous, ranging from big cities like New York, Los Angeles, Philadelphia, and Chicago to mid-sized cities like Oakland, California, to smaller cities, counties, and localities. Most of the organizations were in urban areas, but a handful $(\sim 6)$ were in areas with significant rural populations.

We followed a multi-step process for recruiting research participants. First, we identified a wide range of tenant organizations throughout the country via systematic searches across several platforms (Facebook, Twitter, GuideStar, Google). We primarily searched for the words "tenant" and "renter."7 Once we identified a baseline set of organizations $(\sim 50)$, we then used a virtual snowball approach to find additional organizations. This involved reviewing organizations' websites and social media for any mention of additional organizations. Ultimately, we identified 134 tenant organizations across the country. While this list is certainly not complete in its coverage, it is likely comprehensive. Since tenant organizations are oriented towards building power, most of them want to be found. This gives them an incentive to be visible on the internet, in databases like GuideStar, and on social media. Though we missed organizations, it is also likely that many tenant organizations doing discernable work in local communities were sufficiently visible to be identified via our systematic sweep of a wide variety of platforms.

We reached out to all the organizations whom we could contact via email, Facebook, or Twitter messages. We received "return to sender" messages for only a handful. In the final calculus, we communicated with 127 of the 134 organizations identified. E-mail and social media are imperfect communication channels, so it is entirely possible that some of our messages went to "junk mail" or were otherwise undetected. Moreover, several organizations replied to our outreach but were not in the final pool of interviewees either because they were unable to coordinate an interview time, did not show up for a scheduled interview, or needed approval from a quorum of organizational members before speaking to us. Altogether, we received responses from 42 organizations and completed interviews with members of 38 organizations. In straightforward terms, this means that roughly $33 \%$ of the organizations that we originally contacted responded to us and about $30 \%$ were part of the final pool of participants.

While these numbers may sound low from a sampling-based statistical perspective, they are robust for an in-depth qualitative project. This research is based on the case-study logic as opposed to sampling logic (Small 2009; Yin 2003). Our goal

\footnotetext{
${ }^{6}$ Interviews included people from organizations in the following states: California, Georgia, Ohio, Michigan, New Jersey, New York, Texas, Hawaii, Kentucky, Florida, Wisconsin, Nebraska, Oregon, Indiana, Illinois, Massachusetts, Washington, Pennsylvania, Louisiana, Virginia and Kansas.

7 To refine and focus our searches, we systematically combined these terms with the names of states and all major cities (top 100 largest) to ensure that we would identify place-specific organizations. This statebased approach very much widened our ambit and helped us to locate organizations in less populous states like South Dakota and Idaho.
} 
was not to get a "representative sample" of tenant organizations. Instead, we aimed to get a range of organizational cases that varied along two key axes: geographic context and organizational type. As we will describe below, we achieved this goal. A key indicator that we interviewed enough people/organizations is that we reached saturation - the point where we consistently heard redundant information such that additional cases did not reveal new information (Small 2009).

The interviews occurred via zoom or over the phone, whichever method the participants preferred (the vast majority opted for zoom). Many of the people we interviewed logged on to zoom with their cameras turned on, so we were often able to see them. A relatively small number of interviewees left their cameras off and were not visible. The interviews lasted an average of $56 \mathrm{~min}$. The longest interview was $82 \mathrm{~min}$ and the shortest was $36 \mathrm{~min}$. Most interviews were with one participant, but sometimes multiple organization members would join the zoom call (up to 4 at one time). Moreover, some people would refer other members of their organization to speak to us, so on numerous occasions we separately interviewed different people from the same organization.

The interviews were semi-structured and based on a short interview guide. We left significant leeway so that conversations could unfold organically. We asked all interviewees about how the organization got started, what its main activities were, how it was structured, what challenges it faced, and how it engaged with legal and political systems. We left time at the end of interviews to ask participants if there was anything important that we did not ask (most interviewees supplied us with responses to this prompt). The semi-structured nature of the interviews allowed participants to tell us things we did not inquire about, alert us to connections we had not considered, and describe processes in ways we could not have anticipated. The interviews thus produced precisely the depth of information that we intended. All interviews were recorded and transcribed. The transcripts were then uploaded into Dedoose, a web-based qualitative software program. We used Dedoose to complete several rounds of coding. Dedoose allows for comprehensive and systematic coding to identify main themes and catalogue interview excerpts. The first round of coding was based on an original list of very broad codes drawn from the main questions asked in the interviews. These codes included things like: "origins" (how organizations began), "activities" (what organizations did), "challenges" (what difficulties organizations faced), "political context" (how organizations understood and responded to the political system), and "organizational structure" (how organizations described their own structures). During the first round of coding, we read through the transcripts and created interview excerpts (i.e., relevant quote blocks from interviews) that aligned with these very broad codes. During this round we also conducted "open" coding to generate additional codes and subcodes based on emergent themes (Williams and Moser 2019). The codes developed through the open coding process were both wider ranging and more specific (e.g., this included codes like "power", "elections" "racism" "landlords" "law enforcement" and more). We then completed a second round of coding based on the additional codes and subcodes generated through open coding. This second round of coding further refined our categorization. Finally, subsequent analyses included selective coding, where we integrated codes and reviewed patterns to identify core narratives for a bigger picture 
understanding (Williams and Moser 2019). All the coding for this article was done by a single researcher, so intercoder reliability was not a concern.

\section{The origins of tenant organizations}

We begin our analysis with the origins of tenant organizations. This is an appropriate starting point both because baseline knowledge about such organizations is low and because the beginnings of tenant groups speak to the ways they conceptualize local political economy. To better understand the roots of tenant organizing, we began our interviews with questions related to (1) how the interview participant came to be a part of a tenant organization and (2) how the group they are a part of got started. These questions address the topic of "origins" from two distinct (but occasionally overlapping) vantage points: individual and organizational. Sometimes the person we were interviewing started the organization, so the two origin stories bled together. Other times they remained separate. We relay both kinds of narratives here.

The primary themes that emerged about origins suggested that people were driven to tenant organizing because of their economic ideas, personal experiences, or both. Some people had harrowing experiences of displacement or predation at the hands of landlords or property managers. They had been evicted or otherwise experienced traumatizing life events related to housing. This either motivated them to start a tenant organization or spurred them to join one. Another group of people we interviewed did not necessarily have adverse experiences with housing. Instead, they came to tenant organizing because of a commitment to a set of ideas about politics and the economy. Some participants openly described those ideas as "socialist" or "democratic socialist," but even those who did not use such labels echoed related notions. At the heart of the economic ideas expressed by nearly all the people we interviewed were beliefs that housing should not be a commodity, that the economy was rigged against the working class, that capitalism was deeply flawed, and that tenants needed power to contest oppressive political and economic structures built for the interests of powerful elites and indifferent to the material needs of workingclass people.

\section{Personal experience as a catalyst for tenant organizing}

Personal experiences of harm or displacement were the main issue raised when we asked about the origins of tenant organizing efforts. Marcy, an organizer for a prominent tenant union in a midsized Midwestern city said that she got involved:

because I personally experienced an eviction and it was from one of...the most notorious landlords in the city...it caused me hardship in securing housing for about a year or so, and...in order to really fight what I saw was going on in the city] as far as the high eviction rates and that type of stuff, I thought that we needed a group, and then I heard about the [tenants union]. 
It was very common for interviewees to mention experiences specific to a particular building, landlord, or management company. Two Black women who started a tenant association at a large residential apartment complex in a low-income Northern New Jersey neighborhood explained that they acted because of conditions in their building. Phoebe, the primary initiator of the tenant association said, "I started back in October of 2018 because there were a lot of deficiencies here [in the building] that I noticed." Phoebe first approached Savannah, a neighbor she often had small talk with while waiting for the (frequently malfunctioning) elevator. Savannah decided to work with Phoebe to start a tenants' association because, "a lot of tenants had issues within their homes...you know whether there was a leak or paint or sewer issue or backup of the bathrooms...many things... so we started reaching out to tenants to have meetings on a monthly basis."

Notably, nearly everyone we spoke to from a tenant organization that started in the aftermath of the pandemic mentioned Covid-related experiences as an impetus. Yanlin, an Asian-American woman who helped to start a tenant organization in New York City, explained her trajectory.

I got furloughed and I was just like, I don't know what to do...I don't know how I'm gonna pay rent now because there's this coronavirus going around killing people. So, my friend was just kind of like, 'hey why don't you organize your building?' I was like, 'you know what, okay sure.' I really didn't even think about it that hard, I was just like 'okay, but like how,' and then [my friend was] like, 'here are some resources,' and I was like 'okay,' and then from there, I met my next door neighbors who are also tenants under [the same management company] and then they added me to a signal group, and then we were all in a signal chat with other people who have the same landlord, and then from there...we were like, 'why don't we just form a larger tenant Union?'

Renters were not the only ones motivated to organize in response to housing crises. Indeed, while many of the organizations in this study focused exclusively on renters, a handful $(\sim 6)$ included homeowners facing foreclosure among their "tenant" members. This is how Riley, an organizer at a large city-wide tenant group in Massachusetts, found her way to housing work:

I joined [the organization] in 2011 when the bank foreclosed on my home. And God, I fought for five years, five months, and two days and won my house back in 2017. So, [before that] I was not an organizer. I was a stay-at-home mom, I was a deli professional, I was a customer service rep, I was a store manager.

Beyond lived experiences of economic precarity, some people were motivated when they witnessed the experiences of others or saw firsthand how the housing system operated. Tanvee, a young woman doing tenant organizing in a mid-sized midwestern city, relayed that:

...there was a neighbor of my parents...who was a slumlord locally, who offered to kind of show me around. And he took me around to a bunch of his properties and I discovered him to be not just a landlord but a slumlord, he showed me the gun that he uses to threaten his tenants, to get them out when 
they're behind on rent...I started realizing that the people that I'd grown up around some of them literally made their money off the backs of other people on the other side of town 10 minutes away from where I lived and that was very politicizing because I started to recognize that, I was not necessarily of the community where I grew up but...I had benefited from all of the privileges of living in a lush manicured area going to a great public school going to a great college. So, I had the risk of becoming one of those like oppressive class people, so that kind of motivated me to like to change the course of my life...I became an organizer.

\section{Political ideas as a catalyst for organizing}

While many of the people we spoke to (roughly two-thirds) talked about their connection to tenant organizations through the prism of personal experience, several had only minimal personal experience with housing precarity. Though these folks were renters, they were financially comfortable and adjacent to what many would consider the "middle class." 8 For them, the pull of tenant organizing was rooted in ideas rather than experiences. Those ideas related to larger perspectives towards the economic system that were often cultivated in and by other organizational spaces (e.g., Democratic Socialists of America). Westin, a young Asian-American college graduate in his $20 \mathrm{~s}$, explains his trajectory towards starting a tenants' union in Florida:

I was part of a Socialist Party, and I was talking to a friend, a comrade you know, we were talking, he was part of DSA... he said to me... I'm kind of like sick of doing electoral work, I kind of want to do something, direct and something that directly challenges power, something that's very direct and for the people...And at that time we had [another tenants union] one county up...and they had been doing their own thing and we'd actually been part of that and I had been active and helping them as well, so my friend said you know I want to do something direct like a tenant union, so I said, well then let's do a tenant union.

For Westin, the drive to do "something that directly challenges power" was motivated by viewpoints about power relations and social class. Westin regarded tenant organizing as "another way to...show working class people what they can do." He described his own passion for the work in terms of his desire to alter the dynamics of class relations in his city. Though he did not relay personal experiences of housing insecurity, Westin understood organizing as a process of contextualizing personal experiences within a larger political-economic framework. He noted that,

The struggle, even something as traumatic and frankly, violent as eviction can actually motivate people to be more involved and more engaged through organizing...it's such a direct challenge of material conditions...like [organizing] is a

\footnotetext{
${ }^{8}$ See Michener $(2017 \mathrm{a}, \mathrm{b})$ for a critical perspective on conceptualizing class.
} 
direct relationship between material conditions, especially in [this city] where the divide is so extremely stark...if you could picture it [this one] landlord has property in this Pacific Island... and she had two yachts... and I talked to [her tenants], and you know they're like "Oh, you know, sometimes she comes by and she just like harasses me for like $\$ 50$ " and I'm thinking to myself you got two yachts and you trying to push people for $\$ 50$, what's going on here...like just cartoon levels of like evil, or cartoon levels of violence on the people... there's no respect for tenants... and tenants recognize that and that's why organizing is both crucial and such a good pathway to getting people organized and radicalized because you don't really have to tell people they're being exploited, they know it and you just have to put the pieces together for them and they're, like "oh God!"

Westin was one of numerous people who described tenant organizing in terms of ideas about the political economy. Interviewees with well-developed perspectives on class relations were almost always college educated, and many of them had spent time in graduate school. Accordingly, they were less likely to have taken an experiential route to tenant organizations and more likely to have been spurred by political learning. Matt, a white tenant organizer in Northern California, exemplifies this:

...my path to it was that I went to graduate school, which I call neoliberalism school, where they tell you all about the public-private partnerships and how privatization was going to save the world...It was the most bizarre disorienting experience, knowing that there's a serious problem and the solutions that are being offered are not solutions or they're totally inadequate...So, I got out [of school] and then my rent went up, and that pissed me off even more because, of course, they haven't done anything to the property, it's just sitting here and all of a sudden I'm paying more and more...And so, I got together with a couple friends... and we said "what the hell's going on and what can we do about it?" And so, we did a power mapping exercise of the city...we wanted to know if we're going to dedicate hours of our time of our very limited time, we want it to be towards something that's going to have a real positive impact and everything just lead back to housing... you know class and race inequality... how is our wealth extracted from our communities, the number one way is the landlord, and so again and again and again when you drilled it down, it was like this fucking housing, this housing. It was just clear that tenants were second class to everyone else, and that the relationship between politicians, real estate capital, and working-class people was what was destroying everything so when we got together, the tenants union was kind of born at that point...and here we are now almost three years later.

Some of the tenants we interviewed had dual catalysts of both experience and ideas (even Matt, quoted above, talks about his rent being raised). Altogether, these forces worked in tandem to attract tenants and teach them about organizing. Tenant organizations brought people with very few negative experiences but well-honed ideas about capitalism, racism, and other facets of structural inequality into the same spaces as folks who were on the very edge of economic marginality, even if they 
didn't have well developed theories about why and how they got there. These (often) divergent catalysts for involvement engendered organizations that spanned racial and class boundaries. Moreover, the merging of political experience and political ideas proved instructive for the people involved. Those with experience but without larger economic frameworks for making sense of that experience learned a lot through exposure to the ideas that are circulated in tenant organizations. Before too long, people with otherwise little exposure to politics (formal or informal) were calling each other comrades, talking about the failures of capitalism, and power mapping their local political structures. On the other hand, self-avowed socialists-many of whom were White and/or had elite educational backgrounds - came to tenant organizations in search of political outlets more satisfying than elections but found much more than that. They found an opportunity to engage directly and robustly with people from RCS communities and to learn concretely about the forms of predation and abuse that marginalized people faced.

\section{The structure of tenant organizations}

We asserted earlier that tenant organizations do not neatly fit into existing categories of non-governmental organizations (e.g., non-profit, advocacy group, social movement, etc.). We also suggested that this lack of fit underscores what we might learn from the approaches of tenant organizations to engaging local politics. To build on and contextualize these points, we next describe the structure of the organizations in this study.

Two aspects of organizational structure are especially crucial: (1) funding models and (2) decision-making processes. Funding models concern the resource flows of tenant organizations. Decision-making processes have to do with who can influence organizations' ideas, activities, and direction. Ultimately, these structural features reveal the independent and egalitarian nature of many tenant organizations, highlighting their insistence on being beholden only to tenants, their strategies for remaining "unbought and unbossed," and their institutional commitment to "horizontal" decision-making processes powered by the voices of as many tenant members as possible.

\section{Funding mechanisms and organizational autonomy}

Most of the tenant organizations that were part of the study (26 of 38) were "autonomous" regarding their funding. "Autonomous" is the language that tenant organizations use to refer to the status of having no paid staff and being completely financially independent of any actors besides tenants themselves, especially foundations and government agencies. Many tenant organizations stressed the importance of

\footnotetext{
9 This characterization is inspired by Shirley Chisolm, the first Black women elected to Congress and the first Black major party candidate to run for President. Chisolm famously said: "I am the only unbought and unbossed politician, and I mean that literally.".
} 
the distance that being "autonomous" gave them from non-profit "advocacy" and "service provision" models. Tenant organizations went to great care to protect their autonomy, prioritizing it even over resources that might afford them greater capacity. They relied on membership dues and public donations for a small resource base. Accordingly, they organized activities that were local (because trips to the capital or other parts of the state/country are expensive) and not financially burdensome. The costs that members of tenant groups paid were primarily in the currency of time, energy, and even bodies on the line, but most groups were not financially complex.

The intentional eschewing of a staffed "non-profit" structure often underscored tensions between tenant organizations and what some interviewees called "the nonprofit industrial complex." For example, Tatum, a white woman from a newly started tenant organization in a midsize midwestern city talked about how non-profits can hinder efforts at achieving more transformational policy gains:

[We have] a lot of nonprofits [and] that really affects the landscape...[it's] good work, obviously, but maybe it would otherwise be more radical...there were some of these nonprofits...pushing for a rental registration ordinance that ended up just getting completely watered down...It didn't look anything like we wanted it to...But we just couldn't really reach an agreement, so the coalition kind of broke and they ended up getting a rental registration ordinance that requires random inspections of apartment buildings every 10 years and they only hired like one new inspector to do it. So completely pointless...anytime we're in a policy kind of struggle it can very easily get derailed into compromise because there's just not as much [non-profit] people who want to stick to their guns on it.

Many members of tenant organizations took a critical stance towards non-profits, social service organizations, and advocacy organizations. They took pains to distinguish themselves from such groups, pointing out how their emphases on volunteering their time to build power in communities differed from the service provision emphasis of the "professional class." Tenant organizers sometimes characterized the non-profit orientation as a "charity model" that was about distributing resources and juxtaposed that with a "mutual aid" approach, which was about building power through collectively helping one another. For example, at one tenant union meeting, the conversation centered on the "distinction between a focus on tenants and a focus on housing." At the crux of this delineation was the tenant organizations' belief that "housing type non-profits... are more band-aid[s] and not so much about building tenant power." When this same group later deliberated over their "points of unity"the core principles they all agreed held them together as a group—one member suggested the following point of unity: "We organize for tenant power, not for housing." Another member offered this: "We are not service organizations; we are movement organizations. As such we practice and build solidarity-not charity-across buildings, neighborhoods, borders, and language barriers." Much of this echoed a point of unity from an umbrella organization that coordinates a network for tenant unions, the Autonomous Tenants Union Network (ATUN). One of ATUN's key points of unity is that: 
We fight for tenants, not for housing. We recognize that this is a crisis of tenancy, a crisis of our place in the overall system of social reproduction. Calling this a housing crisis benefits those who design, build, and profit from housing, not the people who live in it. Tenants are full political subjects who will not be liberated by secure housing alone.

In this way, the lines that tenant organizations drew between their work and the work of non-profit/advocacy/service organizations were not about semantic particularities. Instead, members of tenant organizations mapped these organizational categories onto fundamental political alignments. Many tenant organizations operated on the conviction that to build "liberatory" formations that could push back against the power of economic elites, they had to conceive of and talk about their work in ways that reflected their assessment of a grossly unequal capitalist economy. "Autonomy" was an important part of this liberatory lexicon.

Notwithstanding the frequent and important distinctions made between "autonomous" and "staffed" organizations, autonomy was nonetheless important to staffed and funded membership-based, tenant led organizations. Tanvee, the lead organizer at a large and prominent tenant group, was a paid staff member. But she was clear on her organizations' strategies to maintain their autonomy:

We have a couple grants...they're all from foundations. And then, in the last year we've also built a really amazing grassroots individual donor network. We raised like $\$ 75,000$ from individuals last year... and I think there's good arguments to do it like that, it's a way that people feel ownership in a thing, even if it's like a $\$ 1$ or $\$ 5$...I get the fear about an outside person or entity or donors coming in and limiting what organizations are able to do, I think there are ways to design around that so it doesn't happen...like my [tenant led] board, the people who are in charge of hiring me firing me...they're going to hold me accountable to doing the work that I do for them right, so that's a structural way that we reset against some of those kinds of risks...with our fundraising I don't like taking foundation money because it's just rich people money that's redirected...I think as we grow as an organization, we will want to build more and more of this kind of individual donor model of sustaining our work so that we're not actually at risk of being hemmed in or tied to any foundation kind of structure, but I will say, none of the money that we've raised to date has limited the radicalism in our base at all. Like none of it. We chained our fucking bodies to the doors of the courts pissing everyone in town off. There's no one in this town that we haven't pissed off in some way in the past year... we've gotten our people arrested...we've taken people on rent strike, we've come up against corporations...and you know I haven't had a donor call me and be like 'you can't do that shit there are some people who might not renew their sustaining donation' or something like that, it hasn't really limited our ability to do what we need to do.

Riley, a paid organizer on staff at a tenant group in Massachusetts, shared a similar perspective on structuring funding to allow the organization to remain independent. She noted that her group had been, "very intentional not to take any government funding, not even city funding, so that no one can dictate what we can and cannot do 
in order to protect our communities." To enable them to follow through on this commitment, Riley's organization coordinated grassroots fundraising campaigns, which became especially crucial when they realized that foundations were less and less interested in supporting housing organizations:

We noticed in 2016/2017 that housing wasn't a hot topic. When 45 got elected it really moved to immigrants and the grants just weren't there. So, we were like well, we don't really have time to write 25 grants for $\$ 3,000$ a piece. So, we actually developed a really robust grassroots fundraising thing and we do it on our own, it's led by the members...we have this one campaign...we ask 100 people to make the commitment to ask 10 of their friends to donate $\$ 10$ between October 1 and October 10 . So, we raised the $\$ 10,000$ and usually we have matching donations to make it 20,000. And we don't have a dues structure, what we ask people to do is either A: volunteer your time or B: if you can't volunteer then we ask that you become a sustaining donor at $\$ 5$ a month, you know, whatever is affordable for you.

Riley, Tanvee, and most of the other people we spoke to from staffed organizations were well versed in concerns about autonomy ${ }^{10}$ and readily offered sophisticated strategies about how to forefend against being influenced by donors. So, while the "autonomous" versus "staffed" dichotomy was an important way that tenant organizations distinguished themselves from mainstream non-profits and advocacy groups, there were certainly staffed tenant organizations that received outside funding, but nonetheless considered themselves reasonably autonomous as a result of intentional decisions to: (1) tightly control channels of influence that tracked back to economic elites and (2) deeply root themselves in decision-making processes that incorporated tenants. ${ }^{11}$

\section{Decision making processes}

Most of the organizations in this study $(\sim 31)$ were "horizontal" with respect to their decision-making processes. Indeed, the descriptor "horizontal" is one that we picked up from observing tenant organization meetings. In many of these meetings, speakers would emphasize that though they were facilitating, they were not leading. Moreover, most meetings involved shared facilitation duties, a practice that underscored horizontal involvement. For example, at a tenant union meeting for a group in Michigan, the person speaking first stated this general approach with clarity: "there is no hierarchy of the roles, they are all necessary, they are all equally important."

\footnotetext{
10 Scholars have demonstrated the numerous ways that funders-especially foundations-can reshape the priorities of grantee organizations toward more politically moderate goals (e.g., Francis 2019) and away from explicit efforts at organizing and mobilization (e.g., Shanks and SoRelle 2021).

11 It's also worth noting that all of the staffed tenant organizations in our study had a very small staff (between 1 and 6 people). Tenant organizations with large numbers of paid staff members were not common, by design. The commitment to being “tenant led" was at the core of these organizations' identities, and with tenants at the helm, there was less need for lots of staff.
} 
This point was made again and again, and it seemed especially salient in meetings where groups were making decisions.

Several of the tenant meetings we sat in were gatherings explicitly adjudicating decision-making models. For example, we watched as a (different) tenant union in Michigan spent over 4 hours debating their decision-making processes. Stressing that "we don't have leaders here," they struggled over how to maximize the participation of all tenant members. Some members wanted to do this through a "consensus based" voting model that required no decision be made unless everyone in attendance at a given meeting agreed on it. One woman explained the logic of this approach saying that, "rather than a top-down decision model where people vote and then the majority rule...the consensus model says that if someone disagrees you take a moment and discuss." A dissenting group member contended that "consensus doesn't work if people don't feel comfortable showing up and disagreeing." Yet another proposed that consensus was "appropriate for committee and other meetings, but when larger discussions about the union are involved, voting is efficient and can loop in feedback from people who don't attend meetings [through virtual voting]." Ultimately, the group decided on a 2/3 agreement threshold for moving forward with group decisions. Even after this decision, one person offered a final word of caution saying that, "consensus institutionalizes good conversational norms, so if we are going to have a voting system then fine, we just need to make sure we have good conversational norms and make sure people don't feel like they are getting steam rolled over."

The most common answer that members of tenant organizations used when asked to describe how they were structured was "horizontal." But this did not mean that they were unorganized or that it was a chaotic free-for-all. Instead, it meant that there was no single person at the "top" and that every member of the organization was ultimately accountable to other members. We can turn again to Tanvee for an example of what these kinds of arrangements looked like in practice:

So, we have a [tenants] base, this is the core organizing unit...we have weekly base meetings and most of our decisions are made by the full base so mostly we do consensus style decision making in those meetings...Within the base, we have a strategy team and our board of directors. The strategy team is just comprised of leaders from the base, it's not like a separate entity, and the strategy team is empowered by the base to make decisions... the strategy team is like 25 [community] leaders who make decisions on behalf of the base... the Board is also mostly leaders from the base so we don't look like a lot of traditional nonprofits in that our board is all people who are directly impacted...And it's a pretty small board at it's all people from our base and the board actually doesn't make any strategic decisions or programmatic decisions...it's kind of like the operation side."

Riley described a slightly different structural process for decision-making, with resonances of similarity and a particular emphasis on racial equity and centering those who are "affected" by processes like displacement or foreclosure: 
We're fully member led...we spent two years being very intentional about what it looks like to be fully member led because... our original organizers were not affected by displacement or foreclosure. So, we wanted to be fully member led at every single aspect our staff, our entire board. And so, we developed, you know, like our board has to be majority women, majority Black and Brown, being very intentional so that white men cannot come in and take over the organization.

Altogether, most tenant organizations in this study prioritized horizontal decision-making processes marked by maximal and robust tenant involvement and voice. In this way, the structure of tenant organizations mirrored their goals. To build power in communities, they ensured that power was disbursed as equitably as possible within their own groups. This orientation towards horizontality ensured that people affected by the predation and precarity that tenant groups were fighting against, were not just being passively "advocated" for in a general sense but were being actively positioned to influence the processes that shape their material conditions (Michener 2018; Strolovitch 2008).

\section{How tenant organizations engage local politics}

Tenant organizations engage in ways that can have profound repercussions for local politics. They pursue a wide variety of strategies for taking action to affect local communities. The nature and extent of those strategies depend upon organizations' beliefs about the best ways to reach their goals. Many tenant organizations operate from a place of deep distrust in formal political systems, elections, and political officials. This baseline skepticism leads to at least three different organizational approaches: (1) Withdrawal, (2) Integration, and (3) Oppositional Engagement. These sometimes overlap as organizations sometimes blend approaches. However, most organizations have a primary tack that informs their participatory strategies. Below, we describe the resulting manifestations of political action.

\section{Withdrawal: stepping into people power}

Distrust of political and economic systems can motivate withdrawal from engagement with the formal political system. While this was not the path that most tenant organizations in the study took, there were a few $(\sim 3)$ that expressed no desire whatsoever to participate in formal politics. Instead, these organizations aimed to articulate and enact an alternative vision of politics that eschewed existing political institutions and built new ones. One large (e.g., hundreds of members) tenant organization in this study strikingly exemplified the withdrawal approach. At one of the tenant meetings we observed, Joe, a tenant member, explained the group's history with electoral politics. He talked about a politician who once tried to get the group to endorse her campaign. Group members were enthusiastic about the candidate because she opposed displacement and sweeps of encampments for the unhoused. While the tenant organization decided not to formally support the 
candidate (because the group had a rule against doing so), many members worked for this candidate's campaign. Election time arrived and she won. Then, one of her first votes was "against" people who are unhoused and living on the street. The official also took money from developers, and often voted in the interest of landlords. Eventually, the candidate came to the tenant group asking for forgiveness and admitting to voting the wrong way. The group was ultimately relieved that they had not formally endorsed her. One member explained:

The reason why we don't support politicians is because we don't have a system of having them be responsible to us. We give them support and they don't fulfill their side...the power of the people is not going to be won in the hands of the politicians, it is going to be won in our own hands... Seeing her candidacy, I thought there was hope but no, they go into a system and they are eaten up by it, they turn them into the system of power stepping on us tenants...the campaign was so attractive, she said all the right things... and the first months in 3 or 4 votes she's already failing us.

Continuing the conversation, another group member agreed:

I do see more and more that [our organizations'] power is outreach, educating, creating a movement...tenants in crisis that start organizing say that before they found [the organization] they were hopeless but once they found [us] they were able to find courage...that's why I joined [the group] and that's why I'm still a member four years later.

Echoing these sentiments, a third member offered the following:

When we talk about politics we are talking about power, so a conversation that only focuses on councilmembers or the government ignores the fact that there are millions of tenants...when we talk about the ability to have influence in the city it's not about who we are going to elect or what the mayor is going to do, it is about what the [tenants union] is going to do to grow its power...as a union if we are going to talk about politics we have to talk about our power...how do we construct power in our own locals, and our own neighborhoods.

There were 37 people in the zoom breakout room we were in that day, and everyone who spoke (i.e., most people) agreed that engaging formal political officials was not desirable. They talked about "moments of people stepping into their power" in terms of rent strikes, direct action, mutual aid and more. But not in terms of electoral systems or traditional political institutions.

One notable element of such withdrawal was that a significant number of members were immigrants excluded from formal political channels because of their documentation status. Merida, a Latina woman, shared this perspective:

I am a resident with a green card but that status doesn't give me the opportunity to vote or to participate in the legal way that all of you can because I can't vote so for me it's almost automatic that I'm not participating in the political system... there are so many families that don't have documents... 
it's important that we can function outside of that system because people are scared and they don't have access...the question of illegality and that our movement be outside of the system...being in the movement permits me to be active and participate in another way, a more autonomous way, a way that is much more radical.

Throughout the meeting, there was almost complete consensus around the conviction that "developing processes and structures that serve us is so important" because "[formal power] structures clearly aren't there to serve our interests."

\section{Integration: taking over the rent board}

On the other end of the strategic spectrum, some tenant unions make a concerted effort to become integrated into formal political institutions. They view the people leading those institutions as flawed, but not the institutions themselves. They reason that if they can simply replace the people there now with people from their organization, circumstances for tenants would improve. Not many organizations fell into this category, but some did $(\sim 5)$. For example, one group placed several members of their tenant union on the local rent board. Rent board representatives are elected officials who make critical decisions about rent prices and who play a role in adjudicating conflicts between landlords and tenants. When we sat in tenant meetings in cities with rent boards, members were encouraged to attend rent board meetings, run for rent board positions, and more generally to "take over" the entire institution to make it work for the benefit of tenants.

Phoebe, a Black woman mentioned earlier, started a tenant association at her apartment complex in Northern New Jersey. Eventually, she decided to run for a position as a member of the local housing council. Phoebe noted that, "being vocal about [the tenant association] afforded me the opportunity to now be [on the council] for the city...which is another level of addressing housing and seeing housing deficiencies outside of just calling [my landlord], I'm able to see it from a city-wide perspective now."

These examples of tenant organizers integrating into formal political institutions were not common, but the people who shared them were less strident in their perspectives towards government and more mainstream in the kinds of change they called for: focusing on rent control more than rent strikes, affordable housing more than decommodification, and "representing tenant interests" more than building power among tenants.

\section{Oppositional engagement: shutting down court}

Most of the tenant organizations in this study pursued a strategy of intentional opposition and disruption to the formal political system. While this opposition brought them into contact with formal political institutions, that contact was focused on 
fundamental transformation or disruption, often both. For these groups, integrating into the political system was not an option, but neither was fully withdrawing from it. An oppositional engagement strategy allowed tenant organizations to maintain their cynicism towards government and politics, while also taking action to force the hands of government officials they perceived as recalcitrant and hostile. Tanvee's group was a clear example of oppositional engagement.

So, it's kind of part of our DNA to be engaged in that kind of political conversation we have also started seeing those kind of public dialogues as like free spaces, where we get to do political education. We just engaged in this budget process and ...won a million dollars for [tenant advocacy]...within this most recent budget season we've had a basically six week long campaign to get them to commit to that level of funding and, frankly, we didn't think we would win...we were basically doing it to build muscle around the budget process but in the meantime, the positive externalities, we won a million dollars... the budget hearings themselves were like some of the most amazing political theater and political education...we would have like 50 people at a public hearing downtown...the entire place is filled with [our color] shirts. And it's people, one after another, after another, with little two minute testimonies speaking truth to power, and in that telling a story about the perils of racial capitalism and how it shows up in people's lives in [our] city. And not one of those 50 people is saying the words "racial capitalism" because they don't need to, but they're telling their story in a way that makes it so evident that these...monopolies and vulture capitalists that are extracting from our neighborhoods are a force of harm, that the police are a force of harm, that these local agencies are a force of harm...I think we've seen [that] in a city like this, if we are serious about this shit, we can win pretty easily...all it [takes is] us just having the audacity to be like, politics don't have to look like this. Politics could work for us, but we have to step up and make that happen.

Similarly, Phil, a Black organizer in the South, talked about how his tenant group temporarily shut down eviction court and the entire city government:

Some of our more militant members were like "we just got [to] shut it down...what other strategy do we have, the federal government's not coming to help us"...that was also when the $\$ 600$ a week unemployment bonus was going to end so we chose late July in part because we were responding to eviction court reopening and seeing nearly 100 people being evicted every day for the first week...there were two components [to our action] one street theater piece to demonstrate what was going on, we wanted the media seeing us ripping the assholes of our city and state officials and actually laying out why they are responsible for any deaths to come, for anything that comes from these evictions, because they have the power to stop things... so basically folks said let's do a street theater piece...let's just pretend like we're doing some artsy fartsy street theater piece, and then we'll immediately go and lock up. So after we did a street theater piece people immediately went to all the entrances to chain themselves to the gates to prevent 
anyone from going in...we did that before eviction court opened...it was perfect timing and then basically people are chained...the mayor did not want something rowdy because everything that happened with George Floyd...so she was just like don't mess with them, don't mess with them, and so, we were able also shut down City Hall...people went and blocked the entrance to City Hall, so we shut down the entire city government that day.

When we asked Phil whether he had discerned a change in local political dynamics after the shutdown, he noted several things:

We definitely heard less things from tenants about landlords just being A-holes. I think a lot more landlords were willing to negotiate...it also had an impact we believe on illegal evictions...because [landlords] were like wait there's this group of crazy people who are willing to do that and they got away with it. I think it had an impact on discourse about how people think about housing. Also, the judges became more open...there was an election for an eviction court seat...they were all pandering to us, they were pandering out of their asses...so that was an interesting power switch, where now we know the judges are actively aware of what we're doing and what we're putting out into the universe.

Tanvee and Phil offer two examples of how tenant organizations shape the contours of local politics by engaging in oppositional political action. Many similar examples emerged in this study. This was the primary approach taken by tenant groups. Instructively, when we asked them whether they had seen any policy successes or discernable local change as a result, every group recounted specific repercussions stemming from their actions. People we interviewed often pointed us to specific resources, legislation, rules changes, and other outcomes - and many offered concrete evidence of their involvement in political processes as a catalyst to these changes. For example, group members would direct us to watch video of direct-action protests, city council meetings they had taken over, public confrontations with local officials, etc. They would point us to media coverage of these events. Then, they would indicate precisely which political officials responded publicly or privately and trace the path of resources or outcomes (fewer evictions) that flowed from the public pressure they put on those in power. Altogether, tenant organizations offered convincing (even if not dispositive) evidence of their impact in local politics.

\section{Conclusion and future directions}

When the Centers for Disease Control and Prevention (CDC) enacted a nationwide moratorium on evictions as part of their response to the public health crisis created by the Covid-19 pandemic, it sparked a flurry of legal challenges from landlords and associated power brokers in the housing market. Estimates suggest that corporate landlords filed more than 56,000 eviction notices after the order went into effect in September 2020, and tens of thousands of families were evicted as landlords ignored the ban or states failed to enforce it consistently. These conditions, when combined 
with the untold number of renters who endure predatory behavior by landlords and financiers, bring into sharp relief the consequences for race-class subjugated (RCS) communities of a tremendously unequal political economy. But they also demonstrate how local organizations can emerge to directly combat these inequalities, empowering people whose political efficacy and the myriad forms it takes are often too overlooked by political scientists. Tenant organizations are an exemplar of this phenomenon, and our study offers a necessary account of how they emerge, operate, and pursue political change.

Through the careful identification of these organizations and the collection of rich qualitative data, we offer three critical takeaways about tenant organizations as centers of local political power for RCS communities. First, tenant organizations cultivate distinctive perspectives on local political economy, developing unique ideational spaces in local politics. Second, they center the concerns and priorities of economically and racially marginalized communities, both in their organizational practices and in their political action. And third, tenant organizations raise new possibilities for the role of organizations in local politics, especially politics at the margins. For these reasons, tenant groups warrant deeper attention from social scientists.

Our first point, that tenant organizations cultivate distinctive perspectives on local political economy, is especially relevant to building knowledge about the politics of ideas and attitudes. Political attitudes "guide human behavior across domains" in ways that make them potentially powerful determinants of political action and policy outcomes (Hatemi and McDermott 2016). A robust multidisciplinary literature specifically attends to the contours and consequences of political attitudes about the economy and inequality (Blekesaune and Quadagno 2003; Corneo and Grüner 2002; Dawtry et al. 2015; Doherty et al. 2006; Kelly and Enns 2010; Piston 2018; Thal 2017). While important and illuminating, this corpus is dominated by quantitative survey-based approaches focused on individual attitudes (particularly those of middle class or affluent people) measured as separate and disconnected from organizational or community contexts. We offer a very different vantage point on political attitudes by qualitatively examining the ideas about economic and political systems that emerge in local contexts as nurtured by organizational actors. ${ }^{12}$ In doing so, we underscore vital relationships between political ideas, political organizing, and local political economy.

The second takeaway, that tenant organizations center economically and racially marginalized communities in their organizational and political practices, has several implications for how we understand the political power of marginalized people. Notably, these tenant groups are in communities aptly described as "structurally vulnerable" (Michener 2017a, b). That is to say, they emerge in geographically bounded areas that are burdened by concentrated poverty, and in many cases, they are also RCS communities that suffer from punitive expressions of state power. Numerous studies have demonstrated how the consequences of disadvantage multiply for those who live in structurally vulnerable communities (e.g., Chetty et al. 2016; Massey and Denton 1993). But our study suggests the possibility for positive

12 For a similarly distinctive take on political attitudes see: Weaver et al. (2019). 
political engagement to emerge from such communities. And unlike traditional public interest group activity that frequently fails to represent the most marginalized members of groups (Strolovitch 2008), these organizations explicitly center the needs and perspectives of vulnerable members. As such, tenant organizations provide a model for positive political power building for otherwise marginalized constituents.

Finally, our study provides a foundation for future research to address crucial questions about how local organizations emerge and operate to support RCS communities across the United States. One key set of questions concerns the conditions under which tenant (or other similar) organizations are likely to emerge and succeed in achieving their goals. While we have argued that tenant organizations do not conform neatly to a specific organizational type, accounts of their formation, organization, and political activities map onto (and challenge) scholarly expectations about the origins of successful collective action. Interview participants highlight the importance of collective grievance and shared framing for their decisions to form or to join tenant groups, both of which have been demonstrated to boost collective action (Gamson 1992; Klandermans 1997). They also identify how a specific approach to organizational structure and decision making is central to groups' mission and success. The reliance on autonomous funding and horizontal power structures both illuminate the importance of the "mobilizing structure" for successful collective action (McCarthy and Zald 1973; McAdam 1982), while potentially challenging assumptions about what types of structures are sufficient. Finally, they offer unique assessments of local political opportunity structures (McAdam 1982; Tarrow 1998; Tilly 2004) and how those conditions shape their strategies and success. Another critical question that emerges from our study is how and to what extent the person- rather than issue-centered orientation of these groups shapes the prospects for political spillover effects into other arenas of engagement.

While our analysis focuses on tenant organizing, the implications of our findings may travel to other issues of political economy where power and precarity are concentrated at the local level. For example, mobilization to address issues like fringe banking, which most frequently affect structurally vulnerable RCS communities that are geographically bounded, could adopt the logic of tenant organizations to better pursue policy change that benefits and centers those affected by these predatory financial institutions. Furthermore, our analysis suggests that when scholars fail to consider organizing that takes a form distinct from traditional interest group or movement organizations, we fail to identify crucial sources of political power for the most precarious communities. Addressing these and a host of related questions is necessary to more fully understand the contours of local political economy and the possibilities for marginalized actors to successfully exercise political power within profoundly unequal capitalist systems.

Conflict of interest On behalf of all authors, the corresponding author states that there is no conflict of interest. 


\section{References}

Al-Turk, Akram. 2016. Movement Effects on Policy Adoption and Socio-Economic Outcomes: The Case of Affordable Housing Mobilization in the United States.

Andrews, Kenneth T., and Bob Edwards. 2004. Advocacy Organizations in the US Political Process. Annual Review Sociology 30: 479-506.

Atlas, John, and Peter Dreier. 1980. Housing Crisis and the Tenants Revolt. Social Policy 10 (4): 13-24.

Baroni, Laura, Brendan J. Carroll, Adam William Chalmers, Luz Maria Muñoz. Marquez, and Anne Rasmussen. 2014. Defining and Classifying Interest Groups. Interest Groups \&amp; Advocacy 3 (2): 141-159.

Baumgartner, Frank R., and Beth L. Leech. 1998. Basic Interests. Princeton, NJ: Princeton University Press.

Blekesaune, Morten, and Jill Quadagno. 2003. Public Attitudes toward Welfare State Policies: A Comparative Analysis of 24 Nations. European Sociological Review 19 (5): 415-427.

Bougslaw, Daniel. 2020. Rent Strike Nation. The New Republic (March 30). https://newrepublic.com/ article/157081/rent-strike-nation-coronavirus.

Brubaker, Rogers. 2013. Categories of Analysis and Categories of Practice: A Note on the study of Muslims in European Countries of Immigration. Ethnic and Racial Studies 36 (1): 1-8.

Burawoy, Michael, Alice Burton, Ann Arnett Ferguson, and Kathryn J. Fox. 1991. Ethnography Unbound: Power and Resistance in the Modern Metropolis. Berkeley, CA: University of California Press.

Burghardt, Stephen (ed). 1972. Tenants and the Urban Housing Crisis. Dexter, MI: The New Press.

Burns, Rebecca. 2018. Landlords, Your Lease Is Up: A New Movement for Rent Control is Spreading Across the U.S. In These Times (March 5). https://inthesetimes.com/article/landlords-rent-controlhousing-real-estate.

Burnstein, Paul. 2019. The Influence of Organizations on Policy: Theories, Findings, Conclusions. Interest Groups \&amp; Advocacy 8 (1): 1-22.

Burstein, Paul, and April Linton. 2002. The Impact of Political Parties, Interest Groups, and Social Movement Organizations on Public Policy. Social Forces 81 (2): 380-408.

Busch, Clare. 2021. Across the US, the Pandemic has Turned a Generation of Renters into Activists. Equal Times (January 15). https://www.equaltimes.org/across-the-us-the-pandemic-has?lang=en\#. YIwJUi2cZBw.

Capek, Stella, M., and John Ingram Gilderbloom. 1992. Community Versus Commodity: Tenants and the American City. SUNY Press.

Chetty, Raj, Nathaniel Hendren, and Lawrence F. Katz. 2016. The Effects of Exposure to Better Neighborhoods on Children: New Evidence from the Moving to Opportunity Experiment. American Economic Review 106 (4): 855-902.

Cohen, Cathy J. 2004. Deviance as Resistance: A New Research Agenda for the study of Black Politics. DuBois Review 1 (1): 27-45.

Consumer Financial Protection Bureau. 2021 (March). Housing Insecurity and the Covid-19 Pandemic. https://files.consumerfinance.gov/f/documents/cfpb_Housing_insecurity_and_the_COVID-19_ pandemic.pdf.

Corneo, Giacomo, and Hans Peter Grüner. 2002. Individual Preferences for Political Redistribution. Journal of Public Economics 83 (1): 83-107.

Dantzler, Prentiss. 2016. Exclusionary Zoning: State and Local Reactions to the Mount Laurel Doctrine. The Urban Lawyer 48 (3): 653-673.

Dawtry, Rael J., Robbie M. Sutton, and Chris G. Sibley. 2015. Why Wealthier People Think People are Wealthier, and Why it Matters: From Social Sampling to Attitudes to Redistribution. Psychological Science 26 (9): 1389-1400.

Doherty, Daniel, Alan S. Gerber, and Donald P. Green. 2006. Personal Income and Attitudes toward Redistribution: A Study of Lottery Winners. Political Psychology 27 (3): 441-458.

Dreier, Peter. 1982. The Status of Tenants in the United States. Social Problems 30 (2): 179-198.

Dreier, Peter. 1984. The Tenants' Movement in the United States. International Journal of Urban and Regional Research 8 (2): 255-279.

Einstein, Katherine Levine, David M. Glick, and Maxwell Palmer. 2019. Neighborhood Defenders: Participatory Politics and America's Housing Crisis. New York, NY: Cambridge University Press. 
Erickson, David J. 2006. Community Capitalism: How Housing Advocates, the Private Sector, and Government Forged New Low-Income Housing Policy, 1968-1996. Journal of Policy History 18 (2): 167-204.

Feldman, Roberta M., and Susan Stall. 2004. The Dignity of Resistance: Women Residents' Activism in Chicago Public Housing. New York: Cambridge University Press.

Feldman, Roberta M., Susan Stall, Patricia A. Wright, and N. A. Naples. 1998. "The Community Needs to be Built by Us" in Community Activism and Feminist Politics: Organizing across Race, Class and Gender, pp. 257-274 (eds. Nancy A Naples). New York: Routledge.

Fields, Desiree. 2015. Contesting the Financialization of Urban Space: Community Organizations and the Struggle to Preserve Affordable Rental Housing in New York City. Journal of Urban Affairs 37 (2): $144-165$.

Francis, Megan Ming. 2019. The Price of Civil Rights: Black Lives, White Funding, and Movement Capture. Law and Society Review 53 (1): 275-309.

Franko, William W. 2013. Political Inequality and State Policy Adoption: Predatory Lending, Children's Health Care, and Minimum Wage. Poverty \&amp; Public Policy 5 (1): 88-114.

Gamson, William. 1992. "The Social Psychology of Collective Action," in Aldon Morris and Carol McClurg Mueller, eds. 1992. Frontiers in Social Movement Theory. Yale U. Press.

Gillespie, Andra, and Melissa R. Michelson. 2011. Participant Observation and the Political Scientist: Possibilities, Priorities, and Practicalities. PS: Political Science and Politics 44 (2): 261-265.

Gilens, Martin. 2012. Affluence and Influence: Economic Inequality and Political Power in America. Princeton, NJ: Princeton University Press.

Goss, Kristin A. 2013. The Paradox of Gender Equality: How American Women's Groups Gained and Lost their Public Voice. Ann Arbor, MI: University of Michigan Press.

Haag, Matthe and Conor Dougherty. 2020. \#CancelRent is New Rallying Cry for Tenants. Landlords are Alarmed. New York Times (May 1). https://www.nytimes.com/2020/05/01/nyregion/rent-strikecoronavirus.html.

Hajnal, Zoltan L., and Jessica Trounstine. 2016. "Race and Class Inequality in Local Politics." In The Double Bind: The Politics of Racial and Class Inequalities in the Americas, edited by Juliet Hooker and Alvin B. Tillery Jr., pp. 139-155. Washington, DC: American Political Science Association.

Han, Hahrie C. 2009. Moved to Action: Motivation, Participation, and Inequality in American Politics. Palo, Alto, CA: Stanford University Press.

Han, Hahrie C. 2014. How Organizations Develop Activists: Civic Associations and Leadership in the 21st Century. New York, NY: Oxford University Press.

Han, Hahrie, Elizabeth McKenna, and Michelle Oyakawa. 2021. Prisms of the People: Power and Organizing in Twenty-First-Century America. Chicago, IL: University of Chicago Press.

Hatch, Megan E. 2017. Statutory Protection for renters: Classification of State landlord-tenant Policy Approaches. Housing Policy Debate 27 (1): 98-119.

Hatemi, Peter K., and Rose McDermott. 2016. Give Me Attitudes. Annual Review of Political Science 19: 331-350.

Heskin, Allan David. 1981. The History of Tenants in the United States, Struggle and Ideology. International Journal of Urban and Regional Research 5 (2): 178-204.

Howard, Amy L. 2014. More than Shelter: Activism and Community in San Francisco Public Housing. University of Minnesota Press.

Joint Center for Housing Studies. 2020. America's Rental Housing 2020. Harvard University. https:// www.jchs.harvard.edu/sites/default/files/reports/files/Harvard_JCHS_Americas_Rental_Housing_ 2020.pdf.

Kasakove, Sophie. 2019. The Tenants' Rights Movement Is Expanding Beyond Big Cities. The New Republic (May 17). https://newrepublic.com/article/153929/tenants-rights-movement-expan ding-beyond-big-cities.

Kelly, Nathan J., and Peter K. Enns. 2010. Inequality and the Dynamics of Public Opinion: The SelfReinforcing Link between Economic Inequality and Mass Preferences. American Journal of Political Science 54 (4): 855-870.

Kelley, Robin D.G.. 1990. Hammer and Hoe: Alabama Communists During the Great Depression. Chapel Hill: University of North Carolina Press.

Kelley, Robin D.G.. 1996. Race Rebels: Culture, Politics, and the Black Working Class. New York: Simon and Schuster.

Keene, Danya E. 2016. We Need to Have a Meeting: Public Housing Demolition and Collective Agency in Atlanta, Georgia. Housing Policy Debate 26 (1): 210-230. 
Kincaid, John. 1992. From Cooperation to Coercion in American Federalism: Housing, Fragmentation, and Preemption, 1780-1992. Journal of Law \&amp; Politics 9: 333.

Klandermans, Bert. 1997. The Social Psychology of Protest. Oxford, UK: Blackwell Publishers.

Lang, Marissa J. 2019. Rents are Rising, and Neighborhoods are Changing. Renters Mobilized to Form a Tenants Union. The Washington Post (August 23). https://www.washingtonpost.com/local/rentsare-rising-and-neighborhoods-are-changing-renters-mobilized-to-form-a-tenants-union/2019/08/ 22/c3a29286-c2c8-11e9-b72f-b31dfaa77212_story.html.

Lawson, Ronald. 1986. The Tenant Movement in New York City: 1904-1984. New Brunswick: Rutgers University Press.

Lilley, William III. 1980. "The Homebuilders' Lobby” in Housing Urban America edited by Jon Pynoos, Robert Schafer, and Chester W. Hartman. New Brunswick, NJ: Aldine Transaction.

Lowrey, Anne. 2020. Cancel Rent. The Atlantic (May 2). https://www.theatlantic.com/ideas/archive/ 2020/05/cancel-rent/611059/.

Marcuse, Peter. 1980. "The Rise of Tenant Organizations" in Housing Urban America edited by Jon Pynoos, Robert Schafer, and Chester W. Hartman. New Brunswick, NJ: Aldine Transaction.

Marcuse, Peter, and David Madden. 2016. In Defense of Housing: The Politics of Crisis. New York, NY: Verso Books.

Maslow-Armand, Laura. 1986. The Newark Tenant Rent Strike: Public Housing Policy and Black Municipal Governance. Patterns of Prejudice 20 (4): 17-30.

Massey, Douglas S., and Nancy Denton. 1993. American Apartheid: Segregation and the Making of the Underclass. Cambridge, MA: Harvard University Press.

McAdam, Doug. 1982. Political Process and the Development of Black Insurgency, 1930-1970. Chicago: University of Chicago Press.

McAlevey, Jane. 2016. No Shortcuts: Organizing for Power in the New Gilded Age. New York, NY: Oxford University Press.

McCarthy, John D., and Mayer N. Zald. 1973. The Trend of Social Movements in America: Professionalization and Resource Mobilization. Morristown, NJ: General Learning Press.

Michener, Jamila. 2013. Neighborhood Disorder and Local Participation: Examining the Political Relevance of "Broken Windows." Political Behavior 35 (4): 777-806.

Michener, Jamila. 2017a. Social Class as Racialized Political Experience. The Forum 15 (1): 93-110.

Michener, Jamila. 2017b. People, Places, Power: Medicaid Concentration and Local Political Participation. Journal of Health Politics, Policy, and Law 42 (5): 865-900.

Michener, Jamila. 2018. Fragmented Democracy: Medicaid, Federalism, and Unequal Politics. New York: Cambridge University Press.

Michener, Jamila. 2020. Power from the Margins: Grassroots Mobilization and Urban Expansions of Civil Legal Rights. Urban Affairs Review 56 (5): 1390-1422.

Michener, Jamila, Mallory SoRelle and Chloe Thurston. 2020. From the Margins to the Center: A Bottom-Up Approach to Welfare State Scholarship. Perspectives on Politics. https://doi.org/10.1017/ S153759272000359X.

Mollenkopf, John and Jon Pynoos. 1980. "Boardwalk and Park Place: Property Ownership, Political Structure and Housing Policy at the Local Level" in Housing Urban America edited by Jon Pynoos, Robert Schafer, and Chester W. Hartman. New Brunswick, NJ: Aldine Transaction.

Nuamah, Sally A. 2020. The Cost of Participating while Poor and Black: Toward a Theory of Collective Participatory Debt. Perspectives on Politics. https://doi.org/10.1017/S1537592720003576.

PEW Charitable Trust. 2016. Household expenditures and income: Balancing family finances in today's economy. https://www.pewtrusts.org/-/media/assets/2016/03/household_expenditures_and_ income.pdf.

Piven, Frances Fox, Lorraine Carol Minnite, and Margaret Groarke. 2009. Keeping Down the Black Vote: Race and the Demobilization of American Voters. New York: New Press.

Piven, Frances Fox, and Richard Cloward. 1977. Poor People's Movements: Why they Succeed, How they Fail. New York: Vintage.

Piston, Spencer. 2018. Class Attitudes in America: Sympathy for the Poor, Resentment of the Rich, and Political Implications. Cambridge University Press.

Rodriguez, Akira Drake. 2021. Diverging Space for Deviants: The Politics of Atlanta's Public Housing. University of Georgia Press.

Salter, Jim. 2020. Ready for a Rent Strike? The Idea is Gaining Steam During Coronavirus Crisis. USA Today (March 30). https://www.usatoday.com/story/money/2020/03/30/coronavirus-rent-strikeadvocates-major-cities-demand-waiver/5088716002/. 
Scott, James C. 1985. Weapons of the Weak: Everyday Forms of Peasant Resistance. New Haven: Yale University Pres.

Schlozman, Kay Lehman, Sidney Verba, and Henry E. Brady. 2012. The Unheavenly Chorus: Unequal Political Voice and the Broken Promise of American Democracy. Princeton, NJ: Princeton University Press.

Shanks, Delphia and Mallory E. SoRelle. 2021. The Paradox of Policy Advocacy: Philanthropic Foundations, Public Interest Groups, and Second-Order Policy Feedback Effects. Interest Groups \& Advocacy.

Shlay, Anne B., and Robert R. Faulkner. 1984. The Building of a Tenants Protest Organization: An Ethnography of a Tenants Union. Urban Life 12 (4): 445-465.

Skocpol, Theda. 2003. Diminished Democracy: From Membership to Management in American Civic Life. Norman, OK: University of Oklahoma Press.

Skocpol, Theda, Marshall Ganz, and Ziad Munson. 2000. A Nation of Organizers: The Institutional Origins of Civic Voluntarism in the United States. American Political Science Review: 527-546.

Small, Mario Luis. 2009. How Many Cases Do I Need?' On Science and the Logic of Case Selection in Field-based Research. Ethnography 10 (1): 5-38.

SoRelle, Mallory. 2020. Democracy Declined: The Failed Politics of Consumer Financial Protection. Chicago, IL: University of Chicago Press.

Soss, Joe, and Vesla Weaver. 2017. Police Are Our Government: Politics, Political Science, and the Policing of Race-Class Subjugated Communities. Annual Review of Political Science 20: 565-591.

Strolovitch, Dara. 2008. Affirmative Advocacy: Race, Class, and Gender in Interest Group Politics. Chicago: University of Chicago Press.

Tarrow, Sidney G. 1998. Power in Movement: Social Movements and Contentious Politics. Cambridge [England]: Cambridge University Press.

Thal, Adam. 2017. Class Isolation and Affluent Americans' Perception of Social Conditions. Political Behavior 39 (2): 401-424.

Thurston, Chloe N. 2018. At the Boundaries of Homeownership: Credit, Discrimination, and the American State. New York: Cambridge University Press.

Tiebout, Charles M. 1956. A Pure Theory of Local Expenditures. The Journal of Political Economy 64 (5): 416-424.

Tilly, Charles. 2004. Social Movements, 1768-2004. Boulder: Paradigm Publishers.

Tobias, Jimmy. 2019. In the Heart of Real-Estate Power, a Housing Movement Nears Victory. The Nation (May 30). https://www.thenation.com/article/archive/universal-rent-regulation-new-york/.

Trounstine, Jessica. 2018. Segregation by Design: Local Politics and Inequality in American Cities. New York: Cambridge University Press.

Verba, Sidney, Kay Lehman Schlozman, and Henry E. Brady. 1995. Voice and Equality: Civic Voluntarism in American Politics. Cambridge, MA: Harvard University Press.

Weaver, Vesla M., and Amy E. Lerman. 2010. Political Consequences of the Carceral State. American Political Science Review. 104 (4): 817-833.

Weaver, Vesla, Gwen Prowse, and Spencer Piston. 2019. Too Much Knowledge, Too Little Power: An Assessment of Political Knowledge in Highly Policed Communities. The Journal of Politics 81 (3): 1153-1166.

Williams, Rhonda Y. 2004. The Politics of Public Housing: Black Women's Struggles against Urban Inequality. New York: Oxford University Press.

Williams, Michael, and Tami Moser. 2019. The Art of Coding and Thematic Exploration in Qualitative Research. International Management Review 15 (1): 45-55.

Yerena, Anaid. 2015. The Impact of Advocacy Organizations on Low-Income Housing Policy in US Cities. Urban Affairs Review 51 (6): 843-870.

Yerena, Anaid. 2019. Strategic Action for Affordable Housing: How Advocacy Organizations Accomplish Policy Change. Journal of Planning Education and Research: 0739456X19888000.

Yin, Robert K. 2003. Case Study Research: Design and Methods. Thousand Oakes, CA: Sage Publications.

Strolovitch, Dara Z. 2013. Of Mancessions and Hecoveries: Race, Gender, and the Political Construction of Economic Crises and Recoveries. Perspectives on Politics 11 (1): 167-176.

Publisher's Note Springer Nature remains neutral with regard to jurisdictional claims in published maps and institutional affiliations. 